\title{
HR-analyse som ledelseskonsept og ledelsesmote
}

\author{
Av Dag Øivind Madsen og Kåre Slåtten *)
}

Artikkelen drøfter HR-analyse som ledelseskonsept og ledelsesmote. HR-analyse handler om å samle inn og analysere HR-data for å kunne fatte bedre beslutninger og har gjennom de siste årene vokst fram til å bli et svært populært konsept blant praktikere og konsulenter innen HRfeltet. Til tross for konseptets popularitet og oppmerksomhet er det blitt viet lite oppmerksomhet fra forskere. Ved å bruke teorier om ledelseskonsepter og ledelsesmoter er formålet med denne artikkelen å bedre kunne forstå utbredelsen av HR-analyse og de sterke kreftene som står bak spredningen av konseptet. Vi presenterer også noen funn fra virksomheters anvendelse av konseptet.

\section{A. Innledning}

\section{Bakgrunn}

HR-analyse (HRA) er et begrep med stort tolkningsrom og uklart meningsinnhold, og det finnes flere definisjoner (Bassi, 2011; Lawler III, Levenson, \& Boudreau, 2004; Marler \& Boudreau, 2017; Spahic, 2015). Van den Heuvel og Bondarouk (2016, s. 4) definerer HRA som «the systematic identification and quantification of the people drivers of business outcomes, with the purpose to make better decisions». Andre legger vekt på at HRA «is about linking HR decisions to business outcomes and organizational performance» (Marler \& Boudreau, 2017, s. 15). HRA handler med andre ord om å gjøre et systematisk arbeid med å samle inn og analysere relevante HR-data for å ta bedre beslutninger samtidig som man knytter HR-aktiviteter sterkere mot organisatorisk ytelse.

*) Dag Øivind Madsen er ph.d og førsteamanuensis. Kåre Slåtten er cand.polit og førstelektor. Begge forfatterne er knyttet til Høgskolen i Sørøst-Norge (www.usn.no). 
HRA er for tiden viet stor oppmerksomhet i HR-litteraturen (Rasmussen \& Ulrich, 2015; Ulrich \& Dulebohn, 2015). Det fremstår som et buzzword både blant HR-konsulenter og guruer med hyppig oppmerksomhet på konferanser, i bøker og på sosiale medier. Flere har pekt på at det er oppstått en motestrøm rundt HR-analyse, og at det blir sett på som noe organisasjoner «må ha» (Marler, Cronemberger, \& Tao, 2017; Platanou \& Mäkelä, 2016; van den Heuvel \& Bondarouk, 2016). Det kan anses som et element i HR-transformasjonens strategiske partner-rolle (Charlwood \& Hoque, 2017; Ulrich, 2009) og generelt en fremvoksende interesse for evidensbasert praksis (Rousseau, 2012; Rynes, Colbert, \& Brown, 2002; Rynes, Giluk, \& Brown, 2007).

Selv om HRA får stor oppmerksomhet, har det blitt viet lite oppmerksomhet av forskere. Formålet med denne artikkelen er å se nærmere på HRAs framvekst for bedre å kunne forstå hvorfor og hvordan HRA på relativt kort tid har fått den sterke posisjonen i HR-feltet. Som en ramme bruker vi teori om ledelseskonsepter og ledelsesmoter (f.eks. Abrahamson, 1996; Røvik, 2002) for å forstå utviklingsforløpet til HRA. Med bruk av teori om ledelsesmoter legger vi vekt på å forstå ulike tilbudssideaktører og deres posisjonering av HRA.

Teorier om ledelsesmoter har vist seg å ha god forklaringskraft i forbindelse med andre populære HR-konsepter som for eksempel Talent Management (Iles, Preece, \& Chuai, 2010; Preece, Iles, \& Chuai, 2011) og e-HRM (Roeleveld, 2017). I HR-litteraturen har forskere vist at aktører innen HR-feltet er sensitive for institusjonelt press (Boselie et al., 2009; Ewerlin \& Süß, 2016; Gooderham, Nordhaug, \& Ringdal, 1999; Paauwe \& Boselie, 2003, 2007). Som Paauwe og Boselie (2003, s. 64) påpeker, er HR-feltet preget av en rekke «fads» (f.eks. HR Scorecard, HR Metrics, 360 Feedback), der man imiterer det som anses som «best practice». Av den grunn kan teori om ledelsesmoter være en aktuell linse som kan bidra til å en bedre forståelse av spredningen og utbredelsen av fenomenet HRA.

\section{Oversikt over artikkelen}

Artikkelen har følgende oppbygging. I del B gir vi en kort historikk tilbakeblikk på en utvikling som har ledet til framveksten av HRA. I del C ser vi nærmere på HRA som ledelseskonsept og ledelsesmote. Deretter analyserer vi henholdsvis tilbuds- og etterspørselssiden til HRA i del E og F. I del F diskuterer vi funnene i lys av teori om ledelseskonsepter og ledelsesmoter. Avslutningsvis, i del G, konkluderer vi og redegjør for begrensninger og angir forslag til videre studier. 


\section{B. HR-analyse: Et kort historisk tilbakeblikk}

Selv om HR-analyse er et relativt nytt begrep, bygger det på ideer og praksiser som har eksistert i mange årtier innen personal- og HR-feltet (Kaufman, 2007). Bassi (2011) peker på at måling ble diskutert i HR-litteraturen allerede på slutten av 1970-tallet og fikk stadig større oppmerksomhet utover 1980-tallet (Fitz-Enz, 1984). Selv om begrepet HRM kan spores tilbake til Peter Druckers bidrag på midten av 1950-tallet, fikk det sitt virkelige store gjennombrudd på midten av 1980tallet (Beer, 2015; Kaufman, 2015; Marciano, 1995).

På slutten av 1980-tallet og utover 1990-tallet ble fokuset innen organisasjons- og strategiforskningen endret til å se på organisasjonens interne ressurser (f.eks. medarbeidere og organisasjonskultur) som kilder til varige konkurransefortrinn (Barney, 1991; Barney, 1986). Med kunnskapsøkonomiens fremvekst ble de ansatte i langt større grad ansett som en verdifull organisatorisk ressurs og det ble satt fokus på hvordan HR-avdelingen kunne bidra til utviklingen av vedvarende konkurransefortrinn (Barney \& Wright, 1998; Huselid, 1995; Pfeffer, 1994; Ulrich, 1997; Ulrich \& Lake, 1990; Wright, Dunford, \& Snell, 2001). Human- og intellektuell kapital ble sentrale buzzwords både blant forskere og praktikere (Edvinsson, 1997; Stewart, 1997; Ulrich, 1998).

I årene som fulgte, ble det mye oppmerksomhet rundt bruken av nye teknikker og metoder for å kalkulere avkastning på menneskelig og intellektuell kapital (Bontis \& Fitz-Enz, 2002; Fitz-Enz, 2000). På begynnelsen av 2000-tallet ble nye ideer som HR Scorecards og Workforce Scorecards utviklet (Huselid, Becker, \& Beatty, 2005; Ulrich \& Beatty, 2001). Dette var HR-konsepter som var avleggere av det svært innflytelsesrike konseptet Balanced Scorecard (Kaplan \& Norton, 1996). Verktøyene skulle hjelpe organisasjoner med å måle hvilken effekt HR-aktiviteter og praksiser hadde på organisatorisk ytelse.

På midten av 2000-tallet etterlyste man en økt vitenskapelig og evidensbasert tilnærming innen HR-feltet (Boudreau \& Ramstad, 2007; Pfeffer \& Sutton, 2006; Rynes et al., 2002; Rynes et al., 2007). Dette banet veien for et enda sterkere fokus på måling og prediksjon. Utover 2000-tallet ble det publisert et økende antall artikler om HRA i internasjonale tidsskrifter som fokuserer på HR-strategi (f.eks. Feather, 2007; Fink, 2010; Levenson, 2005, 2011 ; Waber, 2013). Særlig de siste fem årene har HRA fått oppmerksomhet i innflytelsesrike praktikerorienterte tidsskrifter som Harvard Business Review (HBR, 2014), og i en rekke rapporter utgitt av globale konsulent- og 
softwareselskaper (f.eks. Deloitte, 2015; Deloitte, 2016, 2017). I omtalen av HRA understreker man den sterke oppmerksomheten som konseptet har blant virksomheter og gevinstene styringsinformasjonen gir for lederes beslutninger. Et viktig fokus innen forskning på HRA er hvordan HRA kan brukes som beslutningsstøtteverktøy for å predikere framtidige hendelser, såkalt «predictive analytics» (Fitz-Enz \& John Mattox, 2014; van den Heuvel \& Bondarouk, 2016, s. 8).

Størstedelen av utviklingen innen HRA har skjedd i kjølvannet av Big Data (Angrave, Charlwood, Kirkpatrick, Lawrence, \& Stuart, 2016). Med muligheter knyttet til «big data» og en videreutvikling av teknologien, har man fått et større potensiale til å bruke informasjon som grunnlag for støtte i beslutningsprosesser (Angrave et al., 2016; Shah, Irani, \& Sharif, 2016).

\section{HR-analyse som ledelseskonsept og ledelsesmote}

\section{HRA som ledelseskonsept}

Ledelseskonsepter har i litteraturen ulike betegnelser som «organisasjonsoppskrifter» (Røvik, 1998), «organisasjonskonsepter» (Benders \& Van Veen, 2001) eller «ledelsesteknologier» (Hansen, 2007; Melander, 2002; Røvik, 2001). Felles for disse betegnelsene er at de peker på at ledelseskonsepter er sterkt normative og gir klare råd og anbefalinger til ledere om hvordan man skal organisere ulike aspekter av ved organisasjoner, for eksempel prosesser eller måle- og rapporteringssystemer.

Det har blitt pekt på at populære ledelseskonsepter ofte har kjennetegn som kan forklare konseptets appell og popularitetspotensiale (Røvik, 2002). I den forbindelse vil vi trekke fram fire kjennetegn som relevante ved HRA (Benders \& Van Veen, 2001; Røvik, 2002): (1) merkelapp, (2) ytelsesforbedringer, (3) tolkningsrom, og (4) universalitet.

For det første må et konsept ha en merkelapp som er «catchy» (Røvik, 1998). På engelsk brukes begrepet «analytics» som uten tvil er en tidsriktig betegnelse som kan sees i sammenheng med Big Data Analytics og evidens. Det andre kjennetegnet ved populære ledelseskonsepter er at det loves store ytelsesforbedringer. Dette gjelder i stor grad for HRA. Man fremhever at bruken av HRA kan hjelpe organisasjoner med å vinne i konkurransen og gi konkurransefortrinn (Soundararajan \& Singh, 2016). Videre har ledelseskonsepter stort tolkningsrom som kan forstås 
på ulike måter (Benders \& Van Veen, 2001). Siden HRA ikke har noen tydelig definisjon kan det tillegges ulikt innhold (Bassi, 2011; Lawler III et al., 2004; Spahic, 2015). Det siste kjennetegnet er knyttet til universalitet, og forklarer hvordan konseptet presenteres som anvendbart og nyttig for organisasjoner på tvers av bransjer og nasjoner. Dette kriteriet passer også godt for HRA siden konseptet gir seg ut for å vær anvendbart i enhver organisasjon uten at man legger vekt på kontekstuelle forhold.

\section{HRA som ledelsesmote}

Analysen i det foregående har vist at det er flere kjennetegn ved HRA som kan forklare konseptets popularitetspotensiale, eller det Røvik (2002) kaller «vinneroppskriften». Likevel er det ikke gitt at konsepter som kan knyttes til slike kjennetegn faktisk blir ledelsesmoter. Litteraturen peker på at konsepter også trenger støtte fra «fashion-setters» (f.eks. konsulenter og guruer) for at det skal få tilstrekkelig oppmerksomhet (Abrahamson, 1996; Kieser, 1997). Konsepter som blir støttet av tilbudssideaktører vil lettere få oppmerksomhet slik at man kan nå en kritisk masse brukere. Det vil igjen trigge såkalte «bandwagon effects» som fører til ytterligere spredning og utbredelse (Benders, 1999). Når konsepters popularitet blir økende trekker det med seg andre aktører, som for eksempel softwareselskaper, som vil utvikle tekniske løsninger knyttet til konseptet (Klincewicz, 2006). I neste del vil vi se nærmere på de ulike aktørene som er å finne i markedet rundt HRA.

\section{HR-analyse: Tilbudssiden}

Det er en rekke aktører i feltet rundt HRA som tilbyr produkter og tjenester knyttet til implementering og anvendelse av HRA. Følgende aktører synes å være særlig innflytelsesrike: 1) konsulentselskaper, 2) teknologiselskaper, 3) bransjeorganisasjoner, 4) konferanse- og seminararrangører, 5) næringslivsmedier, 6) handelshøyskoler, 7) ledelsesguruer, og til slutt, 8) sosiale medier. Hver av aktørene blir belyst nærmere i den videre presentasjonen.

\section{Konsulentselskaper}

Mange peker på konsulenter som en av de mest betydningsfulle aktørene for å forstå hvordan nye organisasjonsideer oppstår og spres (David \& Strang, 2006; Heusinkveld \& Benders, 2012; Jung \& Kieser, 2012; Kieser, 1997; Sahlin-Andersson \& Engwall, 2002). Konsulenter spiller en avgjørende rolle blant annet fordi de er bidragsytere inn mot andre aktører som gir kraftfulle allianser 
(Klincewicz, 2006; Madsen \& Slåtten, 2013). Også for å forstå fremveksten av HRA kan man se en betydelig involvering fra konsulentselskapene.

I løpet av de siste årene har HRA blitt et viktig tjenesteområde for de internasjonale konsulentselskapene, og konseptet er tungt markedsført gjennom selskapenes websider. Bare i løpet av de siste 2-3 år årene har det blitt publisert en rekke rapporter fra ledende konsulentselskaper som McKinsey (Fecheyr-Lippens, Schaninger, \& Tanner, 2015), Boston Consulting Group (BCG, 2014), Accenture (Accenture, 2014), KPMG (KPMG, 2015), og Deloitte (Deloitte, 2015, 2016). Konsulentenes selgende tilnærming har det til felles at HRA inngår som et vesentlig element i fremtidens HR-funksjon dominert av evidensbaserte analyser og digitalisering.

\section{Teknologiselskaper}

Teknologiselskaper spiller en viktig rolle i utviklingen av softwareløsninger for nye ledelsesmoter med teknologisk kjerne (Klincewicz, 2006; Westrup, 2005). Siden HRA må sees i sammenheng med Big Data er det ikke overraskende at teknologiselskaper har spilt en ledende rolle i utviklingen av HRA-feltet. I tillegg er teknologiselskapene kommersielle aktører som betrakter HRA som et lukrativt marked. Markedet knyttet til HR-software er stort og estimert til rundt 14 milliarder USD (Bersin, 2016a).

En rekke velkjente teknologi- og softvareleverandører har utviklet løsninger for HRA og people analytics. For eksempler har selskaper som Oracle, IBM og SAP løsninger som støtter en rekke ulike HR-prosesser (Angrave et al., 2016, s. 5). I tillegg har Google vært tungt involvert i utviklingen av HRA-feltet (Bryant, 2011; Sullivan, 2013), blant annet gjennom oppbyggingen av en egen «people analytics»-avdeling (Davenport, Harris, \& Shapiro, 2010a). Her blir HRA presentert som et vesentlig virkemiddel for å fremskaffe data rundt «talent management».

\section{HR-organisasjoner}

Bransje- og interesseorganisasjoner er en betydningsfull aktør som spiller ulike roller i forbindelse med ledelseskonsepter og ideer (Greenwood, Suddaby, \& Hinings, 2002; Gruen, Summers, \& Acito, 2000). Disse organisasjonene bidrar med opplæring, sertifisering og videreutdanning for sine medlemmer. Gjennom slike aktiviteter påvirker organisasjonene hva som oppfattes som moderne, rasjonelle og legitime ideer. Innen HR-feltet har forskere påpekt at medlems- og 
interesseorganisasjoner har en nøkkelrolle når det gjelder å legitimere ny HR-praksis (Farndale \& Brewster, 2005).

Eksempelvis har HR-feltets interesseorganisasjoner i Norge (www.hrnorge.no), England (www.cipd.co.uk) og USA (www.shrm.org) alle satt HRA høyt på agendaen. Det har blitt arrangert konferanser hvor HR-guruer, eksperter og praktikere har blitt invitert for å presentere sine erfaringer. HR Norge har etablert en nettverksgruppe knyttet til HRA og har de siste årene gjennomført årlige konferanser rundt temaet. HR-guruen Nick Holley har deltatt på flere arrangementer .

\section{Ledelsesguruer}

Ledelsesguruer har stor innflytelse når det gjelder å påvirke spredningen og populariteten til nye ledelseskonsepter og praksiser (Huczynski, 1993; Jackson, 2001). Innenfor HR-feltet generelt sett, er det flere guruer og det foretas årlig rangeringer over de mest innflytelsesrike (HR Magazine, 2016). Ser man mer konsentrert mot HRA er Jac Fitz-Enz (www.drjacanalytics.com) utvilsom en sentral person. I Nord-Amerika er Josh Bersin svært inflytelsesrik og har flere roller i HRA-markedet. Han er leder for Bersin by Deloitte, og en hyppig bidragsyter til mediadiskursen rundt HRA. Bersin er spaltist i næringslivsmagasinet Forbes, og i tillegg har han en webside (www.joshbersin.com) med kommentarer om HRA-relaterte temaer og problemstillinger (f.eks. Bersin, 2016b). Bersin er også aktiv på sosiale medier som YouTube og Twitter. I Europa er Nick Holley ved Henley Business School mye brukt som foredragsholder (f.eks. av HR Norge). På samme måte som Bersin, er Holley aktiv bidragsyter i den offentlige debatten om HRA, særlig på sosiale medier som Twitter. Det er den visjonære fremstillingen av HRA som er særpreget i kommunikasjonen. Man har også en svært selgende tilnærming der man på den ene siden har troverdighet i form av tilhørighet til en akademisk institusjon, samtidig som man har sterke kommersielle interesser.

\section{Konferanser og seminarer}

Konferanser og seminarer er viktige arenaer hvor nye ledelseskonsepter blir introdusert og diskutert (Kieser, 1997). Røvik (1998, s. 293) omtaler det som «utviklingsarenaer». Det vil si møteplasser for deltakere fra ulike organisasjoner som fungerer som yngle- og markedsplasser for omsetning og spredning av moderne organisasjonsoppskrifter. Vanligvis deltar en rekke andre tilbydere (f.eks. konsulenter, softwareselskaper) på slike konferanser og seminarer med faglige 
innlegg og presentasjoner av sine produkter og tjenester. Det har vært en sterk økning i antallet konferanser om HR og people analytics (Green, 2016). Det bør legges til at noen av disse konferansene har blitt arrangert og sponset av velkjente teknologiselskaper (f.eks. IBM) eller handelshøyskoler (f.eks. Wharton). Programmene preges av at det er kjente guruer innen HRA som er «key note speakers». Det er også et relativt stort innslag av konsulentpresentasjoner og caseerfaringer fra virksomheter som har tatt konseptet i bruk.

\section{Næringslivsmedia}

Ulike typer næringslivsmedia er viktige i spredningen av nye ledelseskonsepter (Alvarez, Mazza, \& Pedersen, 2005; Sahlin-Andersson \& Engwall, 2002). Managementlitteratur rettet mot ledere er svært viktig når det gjelder å popularisere nye ideer og praksiser (Furusten, 1999; Røvik, 2002). Bare i løpet av de senere årene har det blitt publisert en omfattende litteratur om HRA (f.eks. Bassi, Carpenter, \& McMurrer, 2010; Davenport, Harris, \& Morison, 2010b; Fitz-Enz, 2010; Isson \& Harriott, 2016; Sesil, 2013; Soundararajan \& Singh, 2016). Litteraturen er lettfattelig fremstilt og baserer seg på en oppskriftsbasert tilnærming for hvordan man går fram.

\section{Handelshøyskoler}

I litteraturen om ledelsesmoter legges det vekt på at handelshøyskoler spiller en viktig rolle når det gjelder å legitimere og sirkulere nye ledelseskonsepter og ideer (Sahlin-Andersson \& Engwall, 2002). Dette gjøres på ulike måter, blant annet ved at konseptene blir integrert i kurs og utdanningsprogrammer.

Nettverket rundt Harvard Business School i USA har spilt en viktig rolle i legitimeringen av HRA. Artikler har vært publisert i Harvard Business Review (Davenport et al., 2010a) og en egen Harvard Business Review Report (HBR, 2014). En rekke professorer ved handelshøyskoler har vært involvert i spredningen av HRA gjennom publiseringer eller innlegg på konferanser. I Skandinavia har man ved CBS en egen gruppe for «human capital analytics» som ledes av professor Dana Minbaeva .

I litteraturen om ledelseskonsepter pekes det på at professorer også kan spille en mer kritisk rolle, gjennom at de utfører «due diligence». Men, som vi har nevnt tidligere, er det få akademikere som har kastet et kritisk søkelys og tatt på seg «outsider»-rollen når det gjelder HRA (van den Heuvel, 2016; van den Heuvel \& Bondarouk, 2016). 


\section{Sosiale medier}

I de siste årene har Internett og sosiale medier vokst fram som viktige kanaler for spredning av informasjon og nyheter om nye ledelseskonsepter og ideer (Madsen \& Slåtten, 2015). En rekke websider og blogger om HR-temaer blir hyppig besøkt av HR-medarbeidere (Jensen-Eriksen, 2016). Eksempler på viktige websider og blogger innen HR-feltet er HR.com, HRN Blog og GlobalHRU.com.

I dag er det mange aktører i HRA-feltet som er aktive på plattformer som LinkedIn, Twitter og YouTube. På LinkedIn finner man flere relevante grupper som «HR Analytics», «People Analytics» og «Workforce Planning and Analytics». Twitter har også blitt en viktig kanal for nyheter og debatt om HRA. En rekke HRA-støttespillere er aktive på Twitter og tweeter ved hjelp av HRA-relaterte hashtags (f.eks. \#HRanalytics, \#PeopleAnalytics, \#HRtech, \#BigData). Det kan også nevnes at søk etter "HR analytics" på YouTube, gir flere tusen hits. Mange av YouTube-videoene involverer de tidligere nevnte HRA-guruene. Videoene understreker betydningen av HRA som et helt nødvendig redskap man må ha og kjenne til. Det gis kortfattede introduksjoner til hvordan man kan komme i gang og flere case-presentasjoner fra virksomheter.

\section{Oppsummering}

I denne delen har vi analysert og beskrevet de ulike aktørene som har vært involvert på HRAs tilbudsside. Analysen av tilbudssiden gir imidlertid kun et partielt bilde av konseptets «fotavtrykk». Spredningen og populariseringen av nye ledelseskonsepter skjer innenfor en markedsplass hvor det også er en etterspørselsside (Abrahamson, 1996; Abrahamson \& Reuben, 2014; Heusinkveld, Sturdy, \& Werr, 2011). I det etterfølgende vil vi kartlegge hvilken betydning et konsept som HRA har på etterspørselssiden (Benders \& Van Veen, 2001; Clark, 2004).

\section{E. HR-analyse: Etterspørselssiden}

Etterspørselssiden omfatter organisasjoner og ledere som er potensielle brukere av HRA. Vi ser først på trender når det gjelder interessen for begrepet HRA, før vi går nærmere inn på forskning som belyser i hvilken grad og på hvilke måter konseptet blir adoptert og implementert i praksis. 


\section{Interesse}

Ved å bruke analyseverktøyet Google Trends (www.google.com/trends) (Choi \& Varian, 2012) kan man ta temperaturen på interessen for ulike ledelseskonsepter. Selv om man bør være forsiktig med å tolke for mye ut av data fra Google Trends, kan det gi en indikasjon på trender når det gjelder interessen for og nyhetsverdien til ledelseskonsepter (Madsen, 2016).

Figur 1 viser at interessen for «HR analytics» har økt betraktelig de siste fem årene, og er per november 2017 på sitt foreløpig høyeste nivå. I samme periode har studier vist at beslektede teknologisk orienterte konsepter som Big Data også har hatt en sterk (til dels «eksplosiv») økning målt gjennom Google-søk (Madsen \& Stenheim, 2016).

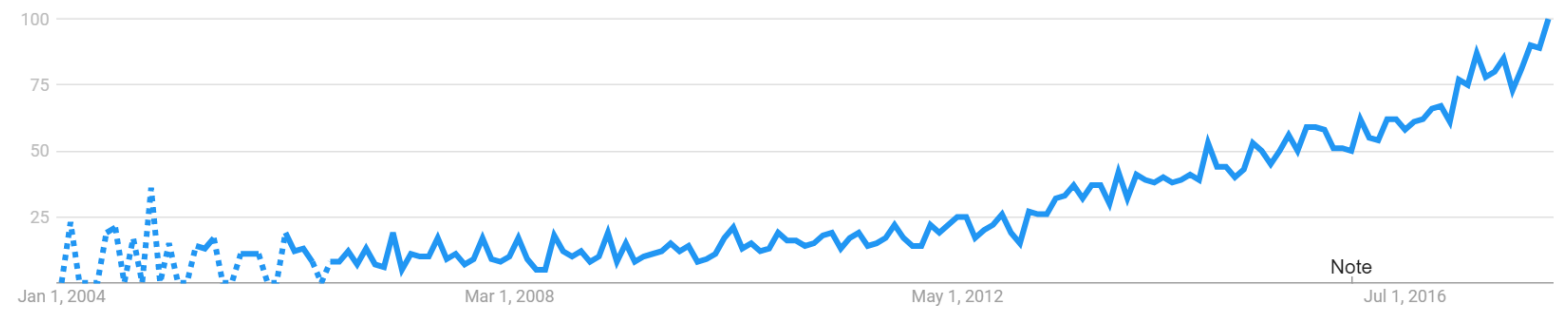

Figur 1: Interessen for «HR analytics» (Datakilde: https://wrww.google.com/trends/, hentet ut 19 november 2017)

Figur 2 sammenligner interessen for «HR analytics» og «HR metrics». HR metrics er et HRkonsept som var svært i vinden på 2000-tallet (Beatty, Huselid, \& Schneier, 2003; Feather, 2007; Lawler III et al., 2004), men figuren viser en noe nedadgående trend for «HR metrics» (rødt). I samme periode har interessen for det nye konseptet «HR analytics» (blått) økt betraktelig. 


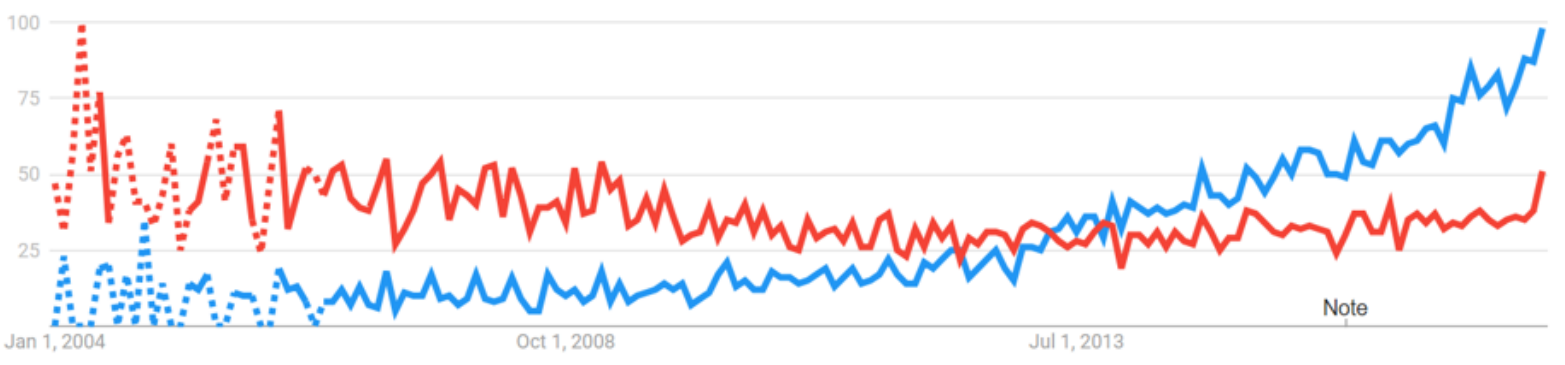

Figur 2: Interessen for «HR analytics» (blått) og «HR metrics» (rødt) (Datakilde: https://wrwergoogle.com/trends/, hentet ut 19 november 2017)

Marler og Boudreau (2017) peker på at det er flere synonyme begreper til HRA som for eksempel «Talent Analytics», «Workforce Analytics», og «People Analytics». Figur 3 viser at HRA (gul kurve) fortsatt er det begrepet som blir søkt etter mest, etterfulgt av «People Analytics».

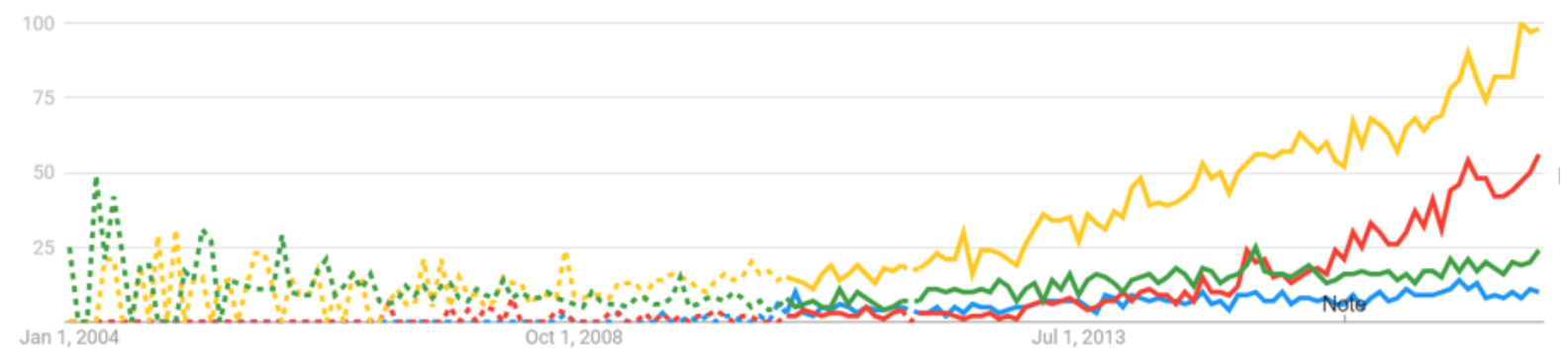

Figur 3: Interessen for «HR Analytics» (gult), «People Analytics» (rødt), «Talent Analytics» (blått) og «Workforce Analytics» (grønt) (Datakilde: https://www.google.com/trends/, hentet ut 21 november 2017)

\section{Adopsjon og implementering}

Selv om HRA får betydelig oppmerksomhet fra tilbudsaktører, er det lite forskning om konseptets bruk og hvilke virkninger det har gitt (Marler \& Boudreau, 2017). En av de tidligste studiene rundt bruken av HRA ble gjennomført for over 10 år siden av Levenson, Lawler og Boudreau (2005). Basert på spørreundersøkelse om HR analyse og transformasjon i 40 selskaper konkluderte de med at HRA kun ble brukt i utstrakt grad i et mindretall av virksomhetene. Noen år senere kartla Falletta (2014) bruken av HRA blant Fortune 1000-selskaper i USA og utvalgte globale selskaper. I denne studien fant man at selskaper med høy ytelse brukte en rekke ulike HRA-relaterte praksiser som gikk utover enkel rapportering. Over $75 \%$ av virksomhetene hadde en egen avdeling som drev med HR-relaterte analyser og rapporteringer. Spahic (2015) fant at 
ledende selskaper ofte brukte avanserte former for HRA (for eksempel «predictive analytics»). Felles for studien til både Falletta (2014) og Spahic (2015) er at det bygger på HR-ansattes selvrapporteringer om HRA med en underliggende antagelse om at det er sammenhenger mellom HR-aktiviteter og organisatorisk ytelse. Dette er premisser som er svært omstridt i HRforskningen (Guest, 2011; Kaufman, 2012).

I 2016 gjennomførte konsulentselskapet Evidente en undersøkelse om HRA i Norge (Evidente, 2016). Den viste at de fleste norske virksomheter fortsatt drev med relativt tradisjonell og enkel HR-rapportering. Få hadde beveget seg mot strategiske og prediktive analyser (Evidente, 2016). Det samme mønsteret fremgår i en publisert undersøkelse fra de nordiske HR-foreningene (Nordic HR Study, 2017). 80 \% av respondentene mente at HRA var viktig, men bare 37 \% var fornøyde med HR-avdelingens bidrag på dette området. Det ble også fremhevet at HRA i hovedsak var konsentrert om deskriptive rapporteringer uten at det prediktive fokuset var vektlagt. Tilsvarende funn ble gjort i en undersøkelse fra Deloitte som konkluderte slik: «While 71 percent of companies see people analytics as a high priority in their organizations (31 percent rate it very important), progress has been slow» (Deloitte, 2017s. 97). Marler og Boudreau (2017, s. 18) peker på mangel på kunnskap som en faktor som kan forklare hvorfor få bedrifter har tatt i bruk HRA: «The most frequently cited reason that HR Analytics is not more widely adopted is the shortage of analytically skilled HR professionals».

Noen forskere har gjort intervjuer med selskaper om deres bruk av HRA (Falletta, 2008; Fink, 2010) og disse studiene viser betydelig variasjon i bruken. Witte (2016) gjennomførte intervjuer med brukere av HRA i Nederland. De fant at alle intervjuobjektene var fornøyde med bruken av HRA og opplevde økende nytte av HRA over tid. Likevel pekes det på at det tar tid å høste eventuelle mulige gevinster av HRA, selv om det var en økende aksept i organisasjonen etter innføringen. Derfor anbefaler Witte (2016) at nye brukere starter i det små og eksperimenter før man implementerer det fullt ut i hele organisasjonen.

\section{F. Diskusjon}

I artikkelen har vi vist at HRA har lange historiske røtter. Teknologi knyttet til utvikling av Big Data har gitt en fornyet interesse for utvikling og popularisering av nye HR-konsepter som HRA. Personal- og HR-funksjonens store utfordringer har til alle tider handlet om hvordan man kan få 
Madsen og Slåtten / HR-analyse som ledelseskonceptog ledelsesmote

økt legitimitet og innflytelse på organisasjonens strategiske valg (Berglund, 2002; Caldwell, 2003; Guest \& King, 2004; Legge, 2005; Ogilvie \& Stork, 2003). Tiltak har blitt iverksatt, nye ideer har blitt lansert, men man vender ofte tilbake til det samme utgangspunktet. Spørsmålet er om HRA kan sees som enda en ledelsesteknologi i rekken av uendelige forsøk på å nå personal- og HRfunksjonens strategiske ideal.

HR-analyse har på relativt kort tid har vokst fram som et ledende konsept innen HR-feltet og det er grunn til å stille spørsmål ved årsaken til den brede appellen. Kieser (1997, s. 61) peker på at timing og tidsriktighet spiller en nøkkelrolle i populariseringen og framvekst av ledelseskonsepter. Konseptene må som han sier treffe en «nerve». Konsepter som passer godt med tidsånden («zeitgeist») vil ha større sannsynlighet for å bli ledelsesmoter. Det ser ut som HRA har en sterk appell i den sterke fremveksten av evidenstekningen i samfunnsvitenskapene (se f.eks. Rousseau, 2012; Young, Ashby, Boaz, \& Grayson, 2002). Som tidligere nevnt, er det også et virkemiddel i HR-funksjonens evige streben for å spille en viktigere og mer strategisk rolle i organisasjoner (Guest \& King, 2004; Kaufman, 2014). Men her kan også HR-funksjonen tape noe av sin særegne identitet som historisk har vært knyttet til å ivareta personaladministrativ stabilitet (Torrington \& Hall, 1996). Flere etterlyser en sterkere etiske orientering rundt HRfunksjonens arbeid, som stadig trekkes tettere mot ledelsesnivået (Caldwell, Truong, Linh, \& Tuan, 201 1; Guest \& Woodrow, 2012; Higgins, Roper, \& Gamwell, 2016; Kochan, 2007; Linehan \& O’Brien, 2016).

Legger vi Jung og Kiesers (2012, s. 329) definisjon av ledelsesmoter til grunn, kan man betrakte HRA som en ledelsesmote siden konseptet på kort tid har fått en stor oppmerksomhet innen den offentlige diskursen om HR og ledelse. Analysen av HRAs tilbudsside har vist at en rekke aktører har vært involvert i framveksten og populariseringen av HRA. Særlig konsulent- og teknologiselskaper har hatt en ledende rolle i disse prosessene foruten nasjonale interesseorganisasjoner innen HR-feltet. Det har også vært en intensiv diskurs om HRA på konferanser, i litteraturen og på sosiale medier. Når det gjelder HRA faktiske utbredelse på etterspørselssiden, er det vanskeligere å gi et klart svar på om det foreløpig har satt særlige spor.

En annen problemstillingen knytter seg til HRAs videre popularitetsutvikling. Platanou og Mäkelä (2016) peker på at oppmerksomheten rundt HRA har vært såpass sterk at konseptet oppfattes som tvingende nødvendig. De hevder også at nytteverdien av HRA ofte er tatt for gitt: 
«the usefulness of big data and analytics in HR is sometimes implicitly taken for granted» (Platanou \& Mäkelä, 2016, s. 23). Med andre ord er HRA sett på som et svært legitimt og sosiale akseptert HR-konsept. Tilbudssideaktørene innen HRA-feltet har bidratt sterkt til spredningen og institusjonaliseringen av HRA gjennom å utføre hva Perkmann og Spicer (2008) kaller «institutional work» (f.eks. publisering av bøker, utdanning av brukere, og etablering av brukernettverk).

Det gjenstår å se hvordan populariteten til HR-analyse vil utvikle seg i framtiden. Basert på den sterke retorikken som eksisterer er det rimelig å anta at forventningene knyttet til ytelsesforbedringer i praksis er ganske høye. Resultatet av dette kan bli at brukerne blir skuffede og desillusjonerte hvis forventningene ikke innfris. Dette kan over tid føre til HRA som konsept blir «utslitt» eller taper sin oppslutning (Benders \& Van Veen, 2001). HR-forskere har derfor advart mot at den sterke interessebølgen ikke er bærekraftig og at den vil kunne visne hen. For eksempel legger Rasmussen og Ulrich (2015) vekt på at HRA bør funderes i faktiske organisatoriske problemer. De stiller også spørsmål ved den faglige interessekampen som kan oppstå siden analytiske problemstillinger tradisjonelt har engasjert andre stillingskategorier (for eksempel staber innen finans, strategi og marketing) i større grad enn HR-funksjonen.

Derfor bør HR-funksjonen involveres og skape et rasjonale for hvorfor det er viktig å samle inn data og gjennomføre analyser. Det kan lett være en risiko for at organisasjoner ender opp med store mengder data som egentlig ikke er nødvendig og ikke brukes for å løse noen faktiske organisatoriske utfordringer. Her må man også legge til at det er det teknologiske managementperspektivet med hovedvekt på evidens, økonomi, analyse og ressursutnyttelse som har oppmerksomhet i dagens HRA-tilnærminger. Måle- og beslutningsproblemer som skal forstå menneskelig atferd kan ikke utelukkende kvantifiseres og objektiviseres. Man må også ta i betraktning andre aspekter som er langt vanskeligere å måle og beskrive digitalt og kvantitativt. Aktørers motivasjon, relasjoner, lojalitet, kreativitet, verdisyn og ikke minst usikkerhetsvurderinger ved fremtidige valg er aspekter som spiller en stadig større rolle for organisasjoners tilpasningsevne. Det er tankevekkende at slike aspekter ser ut til å komme i bakgrunnen for den langt mer kvantitativt orienterte styringslogikken som dominerer HRA og store deler av HRM-tilnærmingen generelt. Det har i den forbindelse vært reist spørsmål om bokstaven H i Human Resource Management er i ferd med å havne i bakgrunn (Bolton \& Houlihan, 2007; Keenoy, 2009; Steers, 2009). 


\section{G. Konklusjon}

Med ledelsesmoter som teoretisk linse har vi i denne artikkelen analysert HRA, et HR-konsept som van den Heuvel (2016) mener har fått lite oppmerksomhet i forskningen Ledelsesmoteteori kan etter vårt skjønn kaste nytt lys på populariseringen og framveksten av HRA. Analysen har vist at det har vært en rekke tilbudssideaktører involvert i HRA-feltet. Særlig har konsulent- og teknologiselskaper hatt en fremtredende rolle. I tillegg har bransje- og interesseorganisasjoner hatt betydning i legitimeringen av HRA i nasjonale kontekster og lokale markeder. Sosiale media har også hatt en rolle i spredningen av populariseringen av HRA. Særlig i forbindelse med teknologisk tunge ledelseskonsepter, som HRA og Big Data, skjer diskursen i stor grad online og ikke i tradisjonelle «brick-and-mortar»-kanaler. Dette kan indikere at sosiale medier er en viktig kanal i populariseringen av dagens ledelsesmoter (Madsen \& Slåtten, 2015).

Artikkelen har fulgt en utforskende tilnærming. Dette gjør at konklusjonene bør anses som tentative. Vi har primært sett på framveksten av HRA fra et tilbudssideperspektiv, siden det er begrenset kunnskap om den faktiske bruken av HRA på etterspørselssiden. I videre studier bør forskere benytte surveytilnærminger og/eller casestudier for å få innsikt i implementering og anvendelse. Det vil også være en styrke om man kan samle inn data over tid, for å kunne si noe om utviklingsforløp.

En annen begrensning ved artikkelen er knyttet til vårt valg av teoretisk perspektiv. Styrken til teorien om organisasjonsmoter er at den er med på å forstå fremveksten og utviklingen av populære ledelseskonsepter og de aktører som er involvert. Det at vi bruker ledelsesmoteteori betyr ikke at vi ser bort fra at HRA kan være nyttig og ha faktiske positive effekter på organisasjoner. Hvis HRA brukes for å løse faktiske organisatoriske problemer kan det være svært nyttig (Rasmussen \& Ulrich, 2015). Ved at HR-funksjonen gjennom sin tilknytning til HRA skal oppnå økt treffsikkerhet i å predikere fremtiden ved hjelp av analyser og estimater, løper man etter vårt skjønn en betydelige risiko. Fremtidsanalyser er forbundet med stor usikkerhet.

Studien har kun sett på HRA ut fra et overordnet internasjonalt makronivå. Marler et al. (2017) peker på at det kan være nyttig å studere spredningen av HRA på tvers av nasjonale kontekster. I framtidige studier kan forskere utføre mer detaljerte casestudier av HRAs popularitetsutvikling i 
ulike land eller regioner. Slik forskning kan omfatte detaljerte kartlegginger av aktivitetene til aktører involvert i lokale markeder, f.eks. lokale konsulentselskaper, ledelsesguruer eller bransjeorganisasjoner. 


\section{Referanser}

Abrahamson, E. 1996. Management Fashion. Academy of Management Review, 21(1): 254-285. https://doi.org/10.5465/amr.1996.9602161572

Abrahamson, E., \& Reuben, A. 2014. The Business Techniques Market Hypothesis: 44. New York, NY: Columbia Business School.

Accenture. 2014. The future of HR: Five technology imperatives.

Alvarez, J. L., Mazza, C., \& Pedersen, J. S. 2005. The Role of the Mass Media in the Consumption of Management Knowledge. Scandinavian Journal of Management, 21(2): 133-233.

https://doi.org/10.1016/j.scaman.2005.02.013

Angrave, D., Charlwood, A., Kirkpatrick, I., Lawrence, M., \& Stuart, M. 2016. HR and analytics: why HR is set to fail the big data challenge. Human Resource Management Journal, 26(1): 1-11. https://doi.org/10.1111/1748-8583.12090

Barney, J. 1991. Firm resources and sustained competitive advantage. Journal of Management, 17(1): 99-120. https://doi.org/10.1177/014920639101700108

Barney, J. B. 1986. Organizational culture: can it be a source of sustained competitive advantage? Academy of management review, 11(3): 656-665. https://doi.org/10.5465/amr.1986.4306261

Barney, J. B., \& Wright, P. M. 1998. On becoming a strategic partner: The role of human resources in gaining competitive advantage. Human Resource Management (1986-1998), 37(1): 31. https://doi.org/10.1002/(SICI) 1099-050X(199821)37:1<31::AID-HRM4>3.0.CO;2-W

Bassi, L. 2011. Raging debates in hr analytics. People and Strategy, 34(2): 14.

Bassi, L., Carpenter, R., \& McMurrer, D. 2010. HR Analytics Handbook: Report of the State of Knowledge: Reed Business, Amsterdam.

BCG. 2014. Creating People Advantage 2014-2015: How to Set Up Great HR Functions. Boston, MA: The Boston Consulting Group, Inc.

Beatty, R. W., Huselid, M. A., \& Schneier, C. E. 2003. New HR Metrics:: Scoring on the Business Scorecard. Organizational Dynamics, 32(2): 107-121. https://doi.org/10.1016/So090$\underline{\text { 2616(03)00013-5 }}$

Beer, M. 2015. HRM at a Crossroads: Comments on "Evolution of Strategic HRM Through Two Founding Books: A 30th Anniversary Perspective on Development of the Field". Human Resource Management, 54(3): 417-421. https://doi.org/10.1002/hrm.21734

Benders, J. 1999. Tricks and Trucks? A Case Study of Organization Concepts at Work. International Journal of Human Resource Management, 10(4): 624-637.

https://doi.org/10.1080/095851999340305 
Benders, J., \& Van Veen, K. 2001. What's in a fashion? Interpretive viability and management fashions. Organization, 8(1): 33-53. https://doi.org/10.1177/135050840181003

Berglund, J. 2002. De otillräckliga. En studie av personalspecialisternas kamp för erkännande. Handelshögskolan i Stockholm.

Bersin, J. 2016a. The HR Software Market Reinvents Itself, Vol. 2016. joshbersin.com.

Bersin, J. 2016b. People Analytics Market Growth: Ten Things You Need to Know, Vol. 2016. Joshbersin.com.

Bolton, S. C., \& Houlihan, M. 2007. Searching for the human in human resource management: theory, practice and workplace contexts. Houndmills: Palgrave Macmillan. https://doi.org/10.1007/978-1137-02023-9

Bontis, N., \& Fitz-Enz, J. 2002. Intellectual capital ROI: a causal map of human capital antecedents and consequents. Journal of Intellectual Capital, 3(3): 223-247.

https://doi.org/10.1108/14691930210435589

Boselie, P., Brewster, C., Paauwe, J., Boon, C., Paauwe, J., Boselie, P., \& Den Hartog, D. 2009. Institutional pressures and HRM: developing institutional fit. Personnel Review, 38(5): 492-508. https://doi.org/10.1108/00483480910978018

Boudreau, J. W., \& Ramstad, P. M. 2007. Beyond HR: The new science of human capital: Harvard Business Press.

Bryant, A. 2011. Google's quest to build a better boss. New York Times, 12.

Caldwell, C., Truong, D. X., Linh, P. T., \& Tuan, A. 2011. Strategic human resource management as ethical stewardship. Journal of Business Ethics, 98(1): 171-182. https://doi.org/10.1007/s10551$\underline{010-0541-y}$

Caldwell, R. 2003. The changing roles of personnel managers: Old ambiguities, new uncertainties. Journal of Management Studies, 4O(4): 983-1004. https://doi.org/10.1111/1467-6486.00367

Charlwood, A., \& Hoque, K. 2017. Managing People: Understanding the Theory and Practice of Human Resource Management. In A. Wilkinson, S. J. Armstrong, \& M. Lounsbury (Eds.), The Oxford Handbook of Management: Oxford University Press.

Choi, H., \& Varian, H. 2012. Predicting the present with google trends. Economic Record, 88(Special Issue, June): 2-9.

Clark, T. 2004. The fashion of management fashion: A surge too far? Organization, 11(2): 297-306. https://doi.org/10.1177/1350508404030659

Davenport, T. H., Harris, J., \& Shapiro, J. 2010a. Competing on talent analytics. Harvard Business Review, 88(10): 52-58. 
Davenport, T. H., Harris, J. G., \& Morison, R. 2010b. Analytics at work: Smarter decisions, better results: Harvard Business Press.

David, R. J., \& Strang, D. 2006. When fashion is fleeting: transitory collective beliefs and the dynamics of TQM consulting. Academy of Management Journal, 49(2): 215-233.

https://doi.org/10.5465/amj.2006.20786058

Deloitte. 2015. Global Human Capital Trends 2015. Leading in the new world of work: Deloitte University Press.

Deloitte. 2016. Global Human Capital Trends 2016. The new organization: Different by design: Deloitte University Press.

Deloitte. 2017. Deloitte Global Human Capital Trends 2017. Rewriting the rules for the digital age. Deloitte University Press.

Edvinsson, L. 1997. Developing intellectual capital at Skandia. Long Range Planning, 30(3): 366373. https://doi.org/10.1016/S0024-6301(97)90248-X

Evidente. 2016. Status HR-analyser: Regn i dag, men utsikt for sol i morgen.

Ewerlin, D., \& Süß, S. 2016. Dissemination of talent management in Germany: myth, facade or economic necessity? Personnel Review, 45(1): 142-160. https://doi.org/10.1108/PR-08-2014-0174 Falletta, S. 2008. HR intelligence: Advancing people research and analytics. IHRIM journal, 12(3): 21-31.

Falletta, S. 2014. In search of HR intelligence: evidence-based HR analytics practices in high performing companies. People and Strategy, 36(4): 28.

Farndale, E., \& Brewster, C. 2005. In search of legitimacy: Personnel management associations worldwide. Human Resource Management Journal, 15(3): 33-48. https://doi.org/10.1111/j.1748$\underline{8583.2005 . t b 00152 . x}$

Feather, K. 2007. Helping HR to measure up: arming the "soft" function with hard metrics. Strategic HR Review, 7(1): 28-33. https://doi.org/10.1108/14754390810847531

Fecheyr-Lippens, B., Schaninger, B., \& Tanner, K. 2015. Power to the new people analytics. McKinsey Quarterly, 51(1): 61-63.

Fink, A. A. 2010. New trends in human capital research and analytics. People and Strategy, 33(2): 14.

Fitz-Enz, J. 1984. How to measure human resources management. New York, NY: McGraw-Hill.

Fitz-Enz, J. 2000. ROI of human capital: Measuring the economic value of employee performance: AMACOM Div American Mgmt Assn.

Fitz-Enz, J. 2010. The New HR Analytics: Predicting the Economic Value of Your Company's Human Capital Investments: AMACOM Div American Mgmt Assn. 
Fitz-Enz, J., \& John Mattox, I. 2014. Predictive analytics for human resources: John Wiley \& Sons. https://doi.org/10.1002/9781118915042

Furusten, S. 1999. Popular Management Books - how they are made and what they mean for organisations. London: Routledge. https://doi.org/10.4324/9780203983706

Gooderham, P., Nordhaug, O., \& Ringdal, K. 1999. Institutional determinants of organizational practices: human resource management in European firms. Administrative Science Quarterly, 44(3): 507-531. https://doi.org/10.2307/2666960

Green, D. 2016. 24 Conferences on People Analytics to attend in 2016/17, Vol. 2016. Linkedin.com.

Greenwood, R., Suddaby, R., \& Hinings, C. R. 2002. Theorizing change: The role of professional assocations in the transformation of institutionalized fields. Academy of Management Journal, 45: 58-80.

Gruen, T., Summers, J. O., \& Acito, F. 2000. Relationship marketing activities, commitment, and membership behaviors in professional associations. Journal of Marketing Management, 64: 34-49. https://doi.org/10.1509/jmkg.64.3.34.18030

Guest, D., \& King, Z. 2004. Power, Innovation and Problem-Solving: The Personnel Managers' Three Steps to Heaven? Journal of Management Studies, 41(3): 401-423.

https://doi.org/10.1111/j.1467-6486.2004.00438.x

Guest, D. E. 2011 . Human resource management and performance: still searching for some answers. Human Resource Management Journal, 21(1): 3-13. https://doi.org/10.1111/j.1748$\underline{8583.2010 .00164 . \mathrm{X}}$

Guest, D. E., \& Woodrow, C. 2012. Exploring the boundaries of human resource managers' responsibilities. Journal of Business Ethics, 111 (1): 109-119. https://doi.org/10.1007/s 10551-012$\underline{1438-8}$

Hansen, C. Ø. 2007. Ledelsesteknologi som begreb - rundt om begrebets meta-teoretiske karakteristika Center for Virksomhedsudvikling og Ledelse, Copenhagen Business School. HBR. 2014. HR Joins the Analytics Revolution, Harvard Business Review Reports.

Heusinkveld, S., \& Benders, J. 2012. Consultants and organization concepts. In M. Kipping, \& T. Clark (Eds.), The Oxford Handbook of Management Consulting: 267-284. New York, USA: Oxford University Press. https://doi.org/10.1093/oxfordhb/9780199235049.013.0013

Heusinkveld, S., Sturdy, A., \& Werr, A. 2011. The co-consumption of management ideas and practices. Management Learning, 42(2): 139-147. https://doi.org/10.1177/1350507610394580

Higgins, P., Roper, I., \& Gamwell, S. 2016. HRM as an emerging new managerial profession. In A. Wilkinson, D. Hislop, \& C. Coupland (Eds.), Perspectives on contemporary professional work: 
challenges and experiences. Cheltenham: Edward Elgar Publishing.

https://doi.org/10.4337/9781783475582.00023

HR Magazine. 2016. HR Most Influential Thinkers.

Huczynski, A. 1993. Management gurus: What makes them and how to become one. London: Routledge.

Huselid, M. A. 1995. The impact of human resource management practices on turnover, productivity, and corporate financial performance. Academy of Management Journal, 38(3): 635-672.

Huselid, M. A., Becker, B. E., \& Beatty, R. W. 2005. The workforce scorecard: Managing human capital to execute strategy: Harvard Business Press.

Iles, P., Preece, D., \& Chuai, X. 2010. Talent management as a management fashion in HRD: towards a research agenda. Human Resource Development International, 13(2): 125-145.

https://doi.org/10.1080/13678861003703666

Isson, J. P., \& Harriott, J. S. 2016. People Analytics in the Era of Big Data: Changing the Way You Attract, Acquire, Develop, and Retain Talent: John Wiley \& Sons.

https://doi.org/10.1002/9781119083856

Jackson, B. 2001 . Management Gurus and Management Fashions. London: Routledge. https://doi.org/10.4324/9780203471999

Jensen-Eriksen, K. 2016. The role of HR analytics in creating data-driven HRM: Textual network analysis of online blogs of HR professionals. Aalto University, Helsinki, Finland.

Jung, N., \& Kieser, A. 2012. Consultants in the Management Fashion Arena. In M. Kipping, \& T. Clark (Eds.), The Oxford Handbook of Management Consulting: 327-346. New York, USA: Oxford University Press. https://doi.org/10.1093/oxfordhb/9780199235049.013.0016

Kaplan, R. S., \& Norton, D. P. 1996. The Balanced Scorecard: Translating Strategy into Action. Boston: Harvard Business School Press.

Kaufman, B., E. 2007. The development of HRM in historical and international perspective. In P. Boxall, J. Purcell, \& P. Wright (Eds.), The Oxford Handbook of Human Resource Management.

Kaufman, B. E. 2012. Strategic human resource management research in the United States: A failing grade after 30 years? The Academy of Management Perspectives, 26(2): 12-36.

https://doi.org/10.5465/amp.2012.0037

Kaufman, B. E. 2014. The development of human resource management across nations: Unity and diversity: Edward Elgar Publishing. https://doi.org/10.4337/9780857932990

Kaufman, B. E. 2015. Evolution of strategic HRM as seen through two founding books: A 30th anniversary perspective on development of the field. Human Resource Management, 54(3): 389-407. https://doi.org/10.1002/hrm.21720 
Keenoy, T. 2009. Human Resource Management. In M. Alvesson, T. Bridgman, \& H. Willmott (Eds.), The Oxford handbook of critical management studies. Oxford: Oxford University Press. https://doi.org/10.1093/oxfordhb/9780199237715.003.0022

Kieser, A. 1997. Rhetoric and myth in management fashion. Organization, 4(1): 49-74. https://doi.org/10.1177/135050849741004

Klincewicz, K. 2006. Management fashions: Turning best-selling ideas into objects and institutions. Piscataway, New Jersey, USA: Transaction Publishers.

Kochan, T., A. 2007. Social Legitimacy of the HRM Profession: A US Perspective. In P. Boxall, P. M. Wright, \& J. Purcell (Eds.), The Oxford Handbook of Human Resource Management. Oxford: Oxford University Press.

KPMG. 2015. Evidence-based HR. The bridge between your people and delivering business strategy: KPMG International.

Lawler III, E. E., Levenson, A. R., \& Boudreau, J. W. 2004. HR metrics and analytics: Use and impact. People and Strategy, 27(4): 27-35.

Legge, K. 2005. Human resource management: rhetorics and realities. Basingstoke: Palgrave Macmillan. https://doi.org/10.1007/978-1-137-03601-8

Levenson, A. 2005. Harnessing the power of HR analytics. Strategic HR Review, 4(3): 28-31. https://doi.org/10.1108/14754390580000607

Levenson, A. 2011 . Using targeted analytics to improve talent decisions. People and Strategy, 34(2): 34.

Levenson, A., Lawler, E., \& Boudreau, J. 2005. Survey on HR Analytics and HR Transformation: Feedback Report. Center for Effective Organizations, University of Southern California.

Linehan, C., \& O'Brien, E. 2016. From tell-tale signs to irreconcilable struggles: The value of emotion in exploring the ethical dilemmas of human resource professionals. Journal of Business Ethics: 1-15.

Madsen, D., \& Slåtten, K. 2013. The Role of the Management Fashion Arena in the CrossNational Diffusion of Management Concepts: The Case of the Balanced Scorecard in the Scandinavian Countries. Administrative Sciences, 3(3): 110-142.

https://doi.org/10.3390/admsci3030110

Madsen, D. Ø. 2016. Using Google Trends in management fashion research: A short note. European Journal of Management, 16(1): 111-122. https://doi.org/10.18374/EJM-16-1.9 Madsen, D. Ø., \& Slåtten, K. 2015. Social media and management fashions. Cogent Business $\Xi^{2}$ Management, 2(1): 1122256. https://doi.org/10.1080/23311975.2015.1122256 
Madsen, D. Ø., \& Stenheim, T. 2016. Big Data viewed through the lens of management fashion theory. Cogent Business \& Management, 3(1): 1165072.

https://doi.org/10.1080/23311975.2016.1165072

Marciano, V. M. 1995. The origins and development of human resource management. Academy of Management Proceedings, 1995(1): 223-227. https://doi.org/10.5465/ambpp.1995.17536494

Marler, J. H., \& Boudreau, J. W. 2017. An evidence-based review of HR Analytics. The International Journal of Human Resource Management, 28(1): 3-26.

https://doi.org/10.1080/09585192.2016.1244699

Marler, J. H., Cronemberger, F., \& Tao, C. 2017. HR Analytics: Here to Stay or Short Lived Management Fashion? In T. Bondarouk, H. J. M. Ruël, \& E. Parry (Eds.), Electronic HRM in the Smart Era: 59-85: Emerald Publishing Limited.

Melander, P. 2002. Økonomistyringens nye ledelsesteknologier: Djøf/Jurist-og Økonomforbundet.

Nordic HR Study. 2017. Nordic HR Study 2017. HR's view on future organizational challenges and opportunities: HR Norge, Flóra, HENRY, Sveriges HR Förening and EY. .

Ogilvie, J. R., \& Stork, D. 2003. Starting the HR and change conversation with history. Journal of Organizational Change Management, 16(3): 254-271. https://doi.org/10.1108/09534810310475514

Paauwe, J., \& Boselie, P. 2003. Challenging 'strategic HRM'and the relevance of the institutional setting. Human Resource Management Journal, 13(3): 56-70. https://doi.org/10.1111/j.17488583.2003.tb00098.x

Paauwe, J., \& Boselie, P. 2007. HRM and societal embeddedness. In P. Boxall, P. M. Wright, \& J. Purcell (Eds.), The Oxford Handbook of Human Resource Management: 166. Oxford: Oxford University Press.

Perkmann, M., \& Spicer, A. 2008. How are Management Fashions Institutionalized? The Role of Institutional Work. Human Relations, 61(6): 811-844.

https://doi.org/10.1177/0018726708092406

Pfeffer, J. 1994. Competitive advantage through people: Unleashing the power of the work force: Harvard Business Press.

Pfeffer, J., \& Sutton, R. I. 2006. Evidence-based management. Harvard Business Revierw, 84(1): 62.

Platanou, K., \& Mäkelä, K. 2016. HR function at the crossroads of digital disruption. Työn Tuuli(1): 19-26.

Preece, D., Iles, P., \& Chuai, X. 2011 . Talent management and management fashion in Chinese enterprises: exploring case studies in Beijing. The International Journal of Human Resource Management, 22(16): 3413-3428. https://doi.org/10.1080/09585192.2011.586870

Rasmussen, T., \& Ulrich, D. 2015. Learning from practice: how HR analytics avoids being a management fad. Organizational Dynamics. https://doi.org/10.1016/j.orgdyn.2015.05.008 
Roeleveld, B. 2017. e-HRM viewed from a management fashion perspective; an exploratory study based on the case study research. University of Twente.

Rousseau, D. M. 2012. The Oxford Handbook of Evidence-Based Management: Oxford University Press. https://doi.org/10.1093/oxfordhb/9780199763986.001.0001

Rynes, S. L., Colbert, A. E., \& Brown, K. G. 2002. HR professionals' beliefs about effective human resource practices: Correspondence between research and practice. Human Resource Management, 41(2): 149-174. https://doi.org/10.1002/hrm.10029

Rynes, S. L., Giluk, T. L., \& Brown, K. G. 2007. The very separate worlds of academic and practitioner periodicals in human resource management: Implications for evidence-based management. Academy of Management Journal, 50(5): 987-1008.

https://doi.org/10.5465/amj.2007.27151939

Røvik, K. A. 1998. Moderne organisasjoner. Oslo: Fagbokforlaget.

Røvik, K. A. 2001. Overføring og oversettelse av ledelsesteknologier i den globale organisasjonslandsby. In S. Jönsson, \& B. Larsen (Eds.), Teori \& Praksis - Skandinaviske perspektiver på ledelse og økonomistyring. København: Jurist- og Økonomforbundets Forlag.

Røvik, K. A. 2002. The secrets of the winners: Management ideas that flow. In K. SahlinAndersson, \& L. Engwall (Eds.), The Expansion of Management Knowledge: Carriers, Ideas and Sources: 113-144. Stanford: Stanford University Press.

Sahlin-Andersson, K., \& Engwall, L. 2002. The expansion of management knowledge: Carriers, flows and sources. Palo Alto, California, USA: Stanford University Press.

Sesil, J. C. 2013. Applying Advanced Analytics to HR Management Decisions: Methods for Selection, Developing Incentives, and Improving Collaboration: FT Press.

Shah, N., Irani, Z., \& Sharif, A. M. 2016. Big Data in an HR context: Exploring organizational change readiness, employee attitudes and behaviors. Journal of Business Research.

Soundararajan, R., \& Singh, K. 2016. Winning on HR Analytics: Leveraging Data for Competitive Advantage: Sage Publications Pvt. Ltd.

Spahic, J. 2015. Exploring HR Intelligence Practices in Fortune 1000 and Select Global Firms. Drexel University.

Steers, I. 2009. The conscientious HR manager and the Rubik's Cube. Personnel Review, 38(6): 605620. https://doi.org/10.1108/00483480910992238

Stewart, T. 1997. Intellectual Capital: The New Wealth of Organizations. New York: Doubleday. Sullivan, J. 2013. How Google is using people analytics to completely reinvent HR. TLNT: The Business of HR, 26. 
Torrington, D., \& Hall, L. 1996. Chasing the rainbow: how seeking status through strategy misses the point for the personnel function. Employee Relations, 18(6): 81-97.

https://doi.org/10.1108/01425459610151475

Ulrich, D. 1997. Human resource champions: The next agenda for adding value and delivering results: Harvard Business Press.

Ulrich, D. 1998. Intellectual capital = Competence x Commitment. Sloan Management Review, 39(2): 15-26.

Ulrich, D. 2009. HR transformation: building human resources from the outside in. New York:

McGraw-Hill.

Ulrich, D., \& Beatty, D. 2001. From partners to players: Extending the HR playing field. Human Resource Management, 40(4): 293-307. https://doi.org/10.1002/hrm.1020

Ulrich, D., \& Dulebohn, J. H. 2015. Are we there yet? What's next for HR? Human Resource Management Review, 25(2): 188-204. https://doi.org/10.1016/j.hrmr.2015.01.004

Ulrich, D., \& Lake, D. G. 1990. Organizational capability: Competing from the inside out: John Wiley $\&$ Sons.

van den Heuvel, S. 2016. HRM scholars, where are you in the HR Analytics debate?

Linkedin.com.

van den Heuvel, S., \& Bondarouk, T. 2016. The rise (and fall) of HR analytics: a study into the future applications, value, structure, and system support, 2nd HR Division International Conference (HRIC). Sydney, Australia. https://doi.org/10.5465/ambpp.2016.10908abstract

Waber, B. 2013. People Analytics: How Social Sensing Technology Will Transform Business and what it Tells Us about the Future of Work: FT Press.

Westrup, C. 2005. Management fashions and information systems. In D. Howcroft, \& E. M. Trauth (Eds.), Handbook of Critical Information Systems Research: 132-151. Cheltenham, UK:

Edward Elgar. https://doi.org/10.4337/9781845426743.00014

Witte, L. 2016. We have HR analytics! So what?: an exploratory study into the impact of HR analytics on strategic HRM. University of Twente.

Wright, P. M., Dunford, B. B., \& Snell, S. A. 2001. Human resources and the resource based view of the firm. Journal of Management, 27(6): 701-721. https://doi.org/10.1177/014920630102700607 Young, K., Ashby, D., Boaz, A., \& Grayson, L. 2002. Social science and the evidence-based policy movement. Social Policy and Society, 1(3): 215-224. https://doi.org/10.1017/S14747446402003068 